\title{
Tourism as an Exit Strategy at Crisis Times
}

\author{
Angela Besana, Anna Maria Bagnasco* \\ Department of Business, Economics and Law, IULM University, Milan, Italy \\ Email: angela.besana@iulm.it
}

Received 30 January 2015; accepted 6 March 2015; published 9 March 2015

Copyright (C) 2015 by authors and Scientific Research Publishing Inc.

This work is licensed under the Creative Commons Attribution International License (CC BY). http://creativecommons.org/licenses/by/4.0/

(c) () Open Access

\section{Abstract}

The contemporary crisis is giving evidence of failing macroeconomic theories and policies, after decades of focusing on the aggregate domestic demand and the role of the public expenditure. The contemporary crisis has shown the weakness of fiscal policy. With very low interest rates, the monetary policy does not seem to provide an alternative exit strategy out of the crisis, too. In this paper we discuss the hypothesis that GDP can still be a reliable estimate of growth. Nevertheless, at crisis times, only if the focus is on the foreign demand like International Tourism Receipts and Exports, and Exports can be an exit strategy. One component of Exports and International Tourism Receipts are worthy of attention. Thanks to a cluster analysis of per year variations of International Tourism Receipts (ITRs), GDP and Exports (World Bank Database) from 2007 to 2011, average positive variations of GDPs are matching with positive ITRs and Exports for "clusters" of countries. Performances of Europe and USA are worse than China, Brazil, India and South Africa and these continents and countries are separated in two different clusters. This result can be related to an increase of trade in emerging economies more than in mature ones, whose exit out of the crisis is much more demanding. The research confirms that Tourism and Exports are having an impact on the growth at different intensities (Europe and America vs. Asia) at crisis times.

\section{Keywords}

Macroeconomics, International Tourism Receipts, GDP, Export, Cluster Analysis

\section{Introduction: What's in the Debate}

The latest financial and real crisis has given evidence that macroeconomics and macroeconomic policies are not always able to predict, estimate and solve cycles of contemporary economies. Above all, while the domestic demand is falling, neither fiscal policies nor monetary ones seem to provide countercyclical solutions.

According to Stiglitz, standard models are not enough [1]. The government is theoretically outside the system

\footnotetext{
*Anna Maria Bagnasco wrote the second paragraph.
} 
with ancillary impacts on the system itself, and macroeconomic agents are not studied in that depth that includes information symmetries and financial constraints. Two major macroeconomic players are, therefore, misunderstood: the State and the Agent. If the State should be designed in order to have an efficient impact on economies, it is a Leviathan who is suffering by huge debts and spreads, instead. Whoever is the Agent, it is not possible to understand his visions and purposes at the macroeconomic level. Behavioural economics was a big achievement in the understanding of expected utilities, values and behaviours. This microeconomic approach should be pervasively accepted by macroeconomists today more than in the past [2].

Where is the theoretical network failing? Are there only wrong links or are any nodes breaking down so that links get weaker and weaker and collapse, either?

One of the nodes is the full understanding of demand and supply behaviours. One of the misleading approaches is in the myth of the never-ending growth of both, above all with a modest consideration of their ecological impacts. As a matter of fact, recent and past societies lived of over-consumption. The over-consumption was not ecological and the supply of the manufacturing industry was not ecological, either. The ecology should refer to the sustainability of supply-chains and consumptions and to their environmental impact. So far, the overconsumption was only able to damage and collapse the ecology. Above all, it showed the fragility of the domestic demand.

As already mentioned, another theoretical node was exaggerated. This was the role of the State or Government. The Giant State is not necessary to an economy that is exhausting resources, especially when the Giant State is an accelerator of this exhaustion. The list of eligible sectors where the State has got a primary role should be also revised. Are we sure that the State should not be limited in the provision of public goods at all? At the same time, arbitrage is nowadays perhaps working better than courts. Neither mercenary soldiers nor a huge public military spending is useful. Public hospitals often survive thanks to multiple transaction costs that accelerate the growth of the public expenditure.

It can be concluded that some nodes and links are abused and extra-nurtured.

On the supply side, GDPs are internationally diminishing. Only some economies are growing at different latitudes. China, Turkey, Poland, Mexico, Brazil are growing though today the growth is continually estimated at lower rates than at the expected ones in 2008 and 2009. On the demand side, domestic consumptions are generally collapsing, though some international trade let some specific industries profit by counter-trends from telecommunication to tourism, from natural resources to refuge goods (gold and the other mining industries).

The tourism industry is foreseen to be leading for some economies that are discovered by new flows of foreign tourists. An ever increasing number of destinations in the worldwide have opened up to and invested in tourism, turning tourism into a key driver of socio-economic progress through exports, the creation of jobs and tertiary industries, and infrastructure development. International tourist arrivals have worldwide shown an uninterrupted growth from 25 million in 1950 to 278 million in 1980, 528 million in 1995, and 1087 million in 2013. International tourist arrivals (overnight visitors) grew by $5 \%$ in 2013, reaching a record 1087 million arrivals worldwide, up from 1035 million in 2012, when the 1 billion mark was exceeded for the first time ever. Europe led the growth in absolute terms, welcoming 29 million more international tourists in 2013, and raising the total to 563 million. Growth (+5\%) was double the region's average for the period 2005-2012 (+2.5\% a year) [3]. This is the Europe where macroeconomic policies, both the fiscal policy and the monetary ones, do not seem able to solve the contemporary crisis.

As a matter of fact, next to the failing Macroeconomic Theory, Macroeconomic policies do not give evidence of any kind of reverse-cyclical impacts. Macroeconomic policies are, instead, unable to stimulate the domestic demand. Both the fiscal policy and the monetary policy are strenuously achieving minor goals than in the past and they are both to be revised and targeted to new goals.

The latest crisis gives evidence that the fiscal policy can be an automatic destabilizer [4]. When there is no possibility of re-design of the public expenditure and this one has been exceeding for decades, the State has inferior roles than in the famous post-1929. Above all, if there is a negative demand shock, if both tax rates are raised and the spending cuts are increased in order to reach the deficit target, a second demand shock will occur, it will reinforce the first shock and will worsen the contraction.

Monetary policy is not of useful help, too. Monetary policy should change targets. Inflation is no longer seen by all as the main target of monetary policy. Stabilising nominal GDP growth would be better. The independence of Banks should be, as a consequence, rewritten. The decision over whether central banks should target in- 
flation or nominal GDP should be made by politicians, not central banks, alone. Banks should also revise their aptitude to credit crunch.

The aim of this paper is to give evidence that with collapsing traditional macroeconomic agents and macroeconomic policies, the openness is the best reply to the crisis. Especially, tourism can be positively connected to GDPs, if we take into account the impact of International Tourism Receipts and Exports. These ones can restore collapsing estimates and credibility of the measure.

This paper is a revised and expanded version of the paper entitled Rethinking Tourism in Macroeconomics presented at the International Conference on Applied Economics (ICOAE2014), Chania, 3-5 July 2014.

\section{GDP, Well-Being and Sustainability}

The dominant indicator used to measure growth today is gross domestic product (GDP), which counts the monetary value of all the finished goods and services produced within a country's borders in a specific time period.

Even if GDP is a crucial measurement of growth, it is not all-encompassing. Besides economic resources, the current well-being has to do with non economic resources, with particular attention to the environmental and social ones. GDP is not suitable to grasp some aspects strictly related to the progress and well-being of the people, for example, it does not take into account those assets that do not have a market and does not consider negative externalities (the external costs related to production activities like pollution, unsustainable exploitation of resources, etc.), the quality of public spending, etc.

Recently has aroused the concern that the GDP's emphasis on quantity encourages depletion of social and natural capital and other policies that undermine quality of life for future generations [5]. Moreover, the way in which statistical figures are reported or used may provide a distorted view of the trends of economic phenomena; consequently the political choices could also be inadequate.

The debate on the need to broaden the horizon of current measures of economic performance, especially those solely based on Gross Domestic Product (GDP) has recently led to develop innovative measurement of wellbeing, taking into account its different aspects: economic, environmental, social, etc.

There is a strong demand in the direction to develop the most appropriate indices to measure progress and well-being of nations: the more accurate the index is, the more adequate the economic and social policies choices could be.

In economic literature, it is possible to find different examples of multidimensional descriptive indicators, built with the aim of measuring well-being and quality of life related to a particular country, region, city, etc. [6]. Each measurement is carried out by combining multiple indicators that focus on the crucial aspects that directly or indirectly influence and determine the quality of life of individuals and communities [7]. The indicators concern education and training, employment, environment, energy, health, human rights, infrastructural equip- ment, public and private safety, recreational and cultural activities, cultural tourism and related industries.

In summary, there is no single definition of well-being, but rather a set of possible aspects that combine to define the meaning in a comprehensive manner. A detailed list of possible factors that can affect a dimension of individual well-being is necessarily incomplete.

Despite the variety of indicators is already available, a comprehensive assessment of sustainability is difficult to establish in a fully consensual way.

The complexity of the phenomenon is such that, in the strict sense, it does not appear yet possible to reach an actual and definitive measurement.

Despite this brief description on the new approaches can measure growth, in this paper we use a more traditional approach: with the aim to investigate the relationship between tourism and growth we use a cluster analysis of GDPs, International Tourism Receipts and Exports, in order to give evidence that GDPs can be positively impacted by the foreign demand when the domestic one is failing. This has different implications for continents and countries and the cluster analysis can be significant. The background on this relationship is referred to the literature of the export-led growth hypothesis and to recent theoretical models that only consider non-traded goods such as tourism [8].

The theme is today worthy of attention. In fact, tourism has been transformed to the prevailing industry in the world for a decade.

According to UNWTO, even in the context of the current global economic downturn, tourism remains one of the most promising sectors for reducing unemployment, considering that job creation in tourism tends to outgrow that of other sectors. 


\section{International Tourism, Export and GDP: A Cluster Analysis of 143 Countries from 2007 to 2011}

Tourism can lead the growth of a country, especially, when any other aggregate expense is rather absent and any macroeconomic policy is not able to stimulate the domestic demand. Especially, the international tourism can have a positive effect on economic growth as it increases employment opportunities, personal incomes, taxes, revenues and investment [9], foreign exchange earnings and, as a consequence, the balance of payment. Tourism stimulates investments in new infrastructures [10], human capital [11] and technology [12]. Furthermore, tourism stimulates other related industries by direct, indirect and induced effects and causes positive economies of scale and scope [13]. Any tourist can appreciate hotels, transport systems, gastronomy, etc. when he is "experiencing the holiday". Once the tourist is back in the home-country, he can "extend experiences and shopping” and, as a consequence, he may import "Made in...” from the most appealing destinations [14] with theoretical models and empirical evidence suggesting that tourism can promote trade [15].

Next to regularly updated data of GDPs, the World Bank usually collects the national accounting of International Tourism Receipts (ITRs) in current US dollars. International Tourism Receipts are expenditures by international inbound visitors, including payments to national carriers for international transport. These receipts include any other prepayment made for goods or services received in the destination country. They may also include receipts from same-day visitors, except when these are important enough to justify separate classification. For some countries they do not include receipts for passenger transport items.

The World Bank database includes Exports of Goods and Services, too. Exports comprise all transactions between residents of a country and the rest of the world involving a change of ownership from residents to nonresidents of general merchandise, net exports of goods, nonmonetary gold, and services.

Thanks to a k-means cluster analysis of per year variations ITRs, GDPs and Exports from 2007 to 2011 for 143 countries, ten clusters were significant, but the analysis here will focus only on the most crowded ones (Table 1).

The positive relation of the three variables is evident, when they all grow. Nevertheless, we can appreciate separating performances for European Economies and USA, who were mostly damaged by the crisis in comparison with countries like Brazil, China, India, South Africa or Russia, who showed better performances.

European Economies with United States (USA) are in the most crowded cluster (43.35 percent of the whole sample). From 2008 to 2009, the decline is confirmed both in Exports, International Tourism Receipts (ITRs) and GDPs. From 2009-2010, Exports and ITRs become positive and GDPs profit by a similar growth. In 2011, GDPs growth is, on average, +9 percent while ITRs increase +9 percent and Exports +16 percent.

In the cluster with Emerging Economies (30.06 percent of the whole sample), we can find Brazil, China, India, South Africa and some other more faster-growing economies than the ones in the previous cluster. This cluster includes Canada, Japan, Argentina and some other countries of the South America (Mexico), too. From 2008 to 2009 all variations are negative. Nevertheless, after 2009, the increasing variations are much more impressive than those ones of the previous cluster. For these countries that were only partially suffering of the crisis, the recovery was faster than in the cluster "Euro Area and USA".

In the cluster "Russia and some other Rich Countries" (8.39 percent of the whole sample), some economies with extra-ordinary performances can be found. The Russian Federation, Saudi Arabia and Oman can be here found. On average, 2008-2009 shows the worst performances of the sample, but afterwards, positive variations are the best of the sample. According to data of the World Bank, ITRs increase +37 percent, Exports increase + 35 percent and GDPs increase +22 percent from 2010 to 2011.

The cluster "MINT and Other Countries" is new evidence. This is a miscellaneous cluster of countries that do not relate to rankings or classifications like BRICS. Indonesia can be here found though it is not matched with other MINT (Mexico, Indonesia, Nigeria and Turkey) countries as in the latest classification by Fraser [16].

In Table 2, the analysis of variance (ANOVA) is significant for all variations that are listed in Table 1.

During the crisis when macroeconomic policies are not able to cause a shock of the domestic expense or demand, when the public expenditure is to be drastically limited after decades of increasing debts, when domestic consumption and investments are depressed by the fiscal burden and when quantitative-easing is not able to solve the credit crunch, international tourism and exports can provide a positive impact. International Tourists' incoming generates cash-flows during the holiday, the business trip and any other experience of "the foreign land". Next to this primary expense of the tourist, there is a secondary expense of shopping after the holiday. Exports of destinations can only increase. 
Table 1. Average performances of 143 countries. Final cluster centers for annual variations of international tourism receipts, GDPs and Exports 2007-2011 (not percentage).

\begin{tabular}{ccccc}
\hline $\begin{array}{c}\text { Clusters and Number of Countries in Each Cluster } \\
\text { out of the Sample of 143 }\end{array}$ & $\begin{array}{c}\text { Euro Area } \\
\text { and USA, 62 }\end{array}$ & $\begin{array}{c}\text { Emerging } \\
\text { Economies, 43 }\end{array}$ & $\begin{array}{c}\text { MINT and Other } \\
\text { Countries, 17 }\end{array}$ & $\begin{array}{c}\text { Russia and Some Other } \\
\text { Rich Countries, } 12\end{array}$ \\
\hline International Tourism Receipts Variation 2008-2007 & 0.14 & 0.01 & 0.32 & 0.11 \\
International Tourism Receipts Variation 2009-2008 & -0.10 & -0.09 & -0.05 & 0.00 \\
International Tourism Receipts Variation 2010-2009 & -0.02 & 0.15 & 0.30 & 0.11 \\
International Tourism Receipts Variation 2011-2010 & 0.09 & 0.08 & 0.24 & 0.30 \\
GDP Variation 2008-2007 & 0.14 & 0.14 & 0.20 & -0.15 \\
GDP Variation 2009-2008 & -0.07 & -0.04 & 0.02 & 0.18 \\
GDP Variation 2010-2009 & 0.03 & 0.17 & 0.12 & 0.22 \\
GDP Variation 2011-2010 & 0.09 & 0.14 & 0.14 & 0.41 \\
Exports Variation 2008-2007 & 0.16 & 0.13 & 0.18 & -0.29 \\
Exports Variation 2009-2008 & -0.16 & -0.15 & -0.06 & 0.28 \\
Exports Variation 2010-2009 & 0.10 & 0.26 & 0.20 & 0.21 \\
Exports Variation 2011-2010 & 0.16 & 0.21 & & 0.35
\end{tabular}

Elaboration with SPSS Software.

Table 2. ANOVA - analysis of variance.

\begin{tabular}{|c|c|c|c|c|c|c|}
\hline & \multicolumn{2}{|c|}{ Cluster } & \multicolumn{2}{|c|}{ Error } & \multirow[b]{2}{*}{ F Test } & \multirow[b]{2}{*}{$\begin{array}{c}\text { Significance } \\
\text { Test }\end{array}$} \\
\hline & $\begin{array}{l}\text { Mean } \\
\text { Square }\end{array}$ & $\begin{array}{c}\text { Degree } \\
\text { of } \\
\text { Freedom }\end{array}$ & $\begin{array}{l}\text { Mean } \\
\text { Square }\end{array}$ & $\begin{array}{l}\text { Degree of } \\
\text { Freedom }\end{array}$ & & \\
\hline International Tourism Receipts Variation 2008-2007 & 0.662 & 9 & 0.023 & 133 & 29.151 & 0.000 \\
\hline International Tourism Receipts Variation 2009-2008 & 123.026 & 9 & 0.016 & 133 & 7481.393 & 0.000 \\
\hline International Tourism Receipts Variation 2010-2009 & 0.424 & 9 & 0.020 & 133 & 20.952 & 0.000 \\
\hline International Tourism Receipts Variation 2011-2010 & 36.972 & 9 & 0.023 & 133 & 1627.995 & 0.000 \\
\hline GDP Variation 2008-2007 & 0.052 & 9 & 0.010 & 133 & 5.418 & 0.000 \\
\hline GDP Variation 2009-2008 & 0.048 & 9 & 0.008 & 133 & 5.786 & 0.000 \\
\hline GDP Variation 2010-2009 & 0.081 & 9 & 0.007 & 133 & 11.305 & 0.000 \\
\hline GDP Variation 2011-2010 & 0.034 & 9 & 0.006 & 133 & 6.044 & 0.000 \\
\hline Exports Variation 2008-2007 & 0.118 & 9 & 0.010 & 133 & 11.459 & 0.000 \\
\hline Exports Variation 2009-2008 & 0.061 & 9 & 0.011 & 133 & 5.579 & 0.000 \\
\hline Exports Variation 2010-2009 & 0.165 & 9 & 0.012 & 133 & 13.532 & 0.000 \\
\hline Exports Variation 2011-2010 & 0.462 & 9 & 0.012 & 133 & 39.272 & 0.000 \\
\hline
\end{tabular}

Elaboration with SPSS Software.

It was here investigated the primary expense of International Tourism Receipts and it was given evidence that positive variations of GDPs are matching with positive variations of ITRs and Exports. The cluster analysis emphasized differences among "regions" or continents. Europe and USA are relatively worse than emerging economies (or faster growing ones of the latest classification). These better performances can be related to an increase of trade in emerging economies more than mature ones. These ones are looking at emerging economies as commercial partners and, as a consequence, most of business trips are targeting emerging economies, in order to reach wealthy consumers and in order to implement partnerships with wealthy investors. 


\section{Conclusions}

Macroeconomics and macroeconomic policies are not solving failures of the contemporary crisis. At the same time, measures like GDPs are showing their methodological weakness in order to estimate growth and well-being.

The cluster analysis of the World Bank database for a sample of 143 countries is aimed to investigate variations of GDPs, ITRs and Exports from 2007 to 2011. This analysis confirms that increasing of ITRs and Exports is matching with increasing GDPs. Nevertheless, there are differences between mature, emerging and rich economies in the speed of this nonparallel growth.

One limitation of this investigation is the combination of International Tourism Receipts and Exports. ITR is the primary expense of the tourist abroad, but Exports do not only include the expenditure after having been abroad. And it is difficult to separate this kind of after-experience expense in the accounting line "Exports".

After months of quantitative easing, USA monetary policy is now turning to tapering. If this trend could be evident of the exit of the crisis, it would be interesting to investigate whether monetary policies might accelerate some mature economies out of the crisis. Either monetary policies can be subsidiary or they can be complementary of the foreign demand. Particularly, the debate is still quite heated in Europe, if monetary polices can play some role in order to enable the recovery. Above all, now that the European Central Bank has approved an unparallel quantitative easing.

Some data of China and Brazil economies are lately contradicting the myth of the accelerated growth.

In conclusion, tourism is positively affecting the exit out of the crisis. Nevertheless, it cannot be forgotten that tourism can also damage economies from pollution to the opportunity costs of industries (especially, the manufacturing ones), whose growth is not more supported in order to invest in tourism.

At these hard times and when considering the failure of macroeconomic policies, rethinking the role of tourism in macroeconomics is a binding commitment. This research is an attempt to show the added value of this macroeconomic stabilizer.

\section{References}

[1] Stiglitz, J.E. (2011) Rethinking Macroeconomics: What Failed and How to Repair It. Journal of the European Economic Association, 9, 591-645. http://dx.doi.org/10.1111/j.1542-4774.2011.01030.x

[2] Hoff, K. and Stiglitz, J.E. (2010) Equilibrium Fictions: A Cognitive Approach to Societal Rigidity. American Economic Review, 100, 141-146. http://dx.doi.org/10.1257/aer.100.2.141

[3] UNWTO (2014) Tourism Highlights. World Tourism Organization (UNWTO), Madrid.

[4] Case, K.E., Fair, R.C. and Oster, S.C. (2012) Principles of Economics. Prentice Hall, Upper Saddle River.

[5] Costanza, R., Hart, M., Posner, S. and Talberth, J. (2009) Beyond GDP: The Need for New Measures of Progress. The Pardee Papers, No. 4, Boston University, Boston. http://www.bu.edu/pardee/files/documents/PP-004-GDP.pdf

[6] Lawn, P.A. (2005) An Assessment of the Valuation Methods Used to Calculate the Index of Sustainable Economic Welfare (ISEW), Genuine Progress Indicator (GPI), and Sustainable Net Benefit Index (SNBB). Environment, Development, and Sustainability, 7, 185-208. http://dx.doi.org/10.1007/s10668-005-7312-4

[7] Costanza, R., Fisher, B., Ali, S., Beer, C., Bond, L., Boumans, R., et al. (2007) Quality of Life: An Approach Integrating Opportunities, Human Needs and Subjective Well-Being. Ecological Economics, 61, 267-276. http://dx.doi.org/10.1016/j.ecolecon.2006.02.023

[8] Balaguer, J.M. and Cantavella-Jorda, M. (2002) Tourism as a Long-Run Economic Growth Factor: The Spanish Case. Applied Economics, 34, 877-884. http://dx.doi.org/10.1080/00036840110058923

[9] Lee, C.C. and Chang, C.P. (2008) Tourism Development and Economic Growth: A Closer Look at Panels. Tourism Management, 29, 180-192. http://dx.doi.org/10.1016/j.tourman.2007.02.013

[10] Sakai, M. (2009) Public Sector Investment in Tourism Infrastructure. In: Dwyer, L. and Forsyth, P., Eds., International Handbook on the Economics of Tourism, Edward Elgar, Cheltenham, 266-280.

[11] Blake, A., Sinclair, M.T. and Campos Soria, J.A. (2006) Tourism Productivity: Evidence from the United Kingdom. Annals of Tourism Research, 33, 1099-1120. http://dx.doi.org/10.1016/j.annals.2006.06.001

[12] Lemmetyinen, A. and Go, F.M. (2009) The Key Capabilities Required for Managing Tourism Business Networks. Tourism Management, 30, 31-40. http://dx.doi.org/10.1016/j.tourman.2008.04.005

[13] Weng, C.C. and Wang, K.K. (2004) Scale and Scope Economies of International Tourist Hotels in Taiwan. Tourism Management, 25, 761-769. http://dx.doi.org/10.1016/j.tourman.2004.06.005 
[14] Pinna, A.M. (2011) Visit and Buy. An Empirical Analysis on Tourism and Export. CRENoS Centro Ricerche Economiche Nord Sud Working Paper, Università degli Studi di Cagliari, Cagliari.

[15] Gil-Alana, L.A. and Fischer, C. (2010) International Travelling and Trade: Further Evidence for the Case of Spanish Wine Based on Fractional Vector Autoregressive Specifications. Applied Economics, 42, 2417-2434.

http://dx.doi.org/10.1080/00036840701858083

[16] Fraser, I. (2011) Fidelity Is Confident Its MINTs Won’t Suck. Bloomsbury Information. 